$12-2016$

\title{
Book Review: Man or Monster? The Trial of a Khmer Rouge Torturer
}

Timothy Williams

University of Marburg

Follow this and additional works at: https://digitalcommons.usf.edu/gsp

\section{Recommended Citation}

Williams, Timothy (2016) "Book Review: Man or Monster? The Trial of a Khmer Rouge Torturer," Genocide Studies and Prevention: An International Journal: Vol. 10: Iss. 3: 98-100.

DOI:

http://doi.org/10.5038/1911-9933.10.3.1457

Available at: https://digitalcommons.usf.edu/gsp/vol10/iss3/12

This Book Review is brought to you for free and open access by the Open Access Journals at Digital Commons @ University of South Florida. It has been accepted for inclusion in Genocide Studies and Prevention: An International Journal by an authorized editor of Digital Commons @ University of South Florida. For more information, please contact digitalcommons@usf.edu. 
Book Review: Man or Monster? The Trial of a Khmer Rouge Torturer

\author{
Timothy Williams \\ University of Marburg \\ Marburg, Germany
}

Man or Monster? The Trial of a Khmer Rouge Torturer

Alexander Laban Hinton

Durham, Duke University Press, 2016

360 Pages; Price: \$26.95 Paperback

Reviewed by Timothy Williams

Centre for Conflict Studies at Marburg University (Germany)

As I write this review, the Supreme Court Chamber of the Extraordinary Chambers in the Courts of Cambodia (ECCC) announced their verdict upholding large parts of the judgment in cases 002/01 against Nuon Chea and Khieu Samphan, the second and third defendants at this hybrid tribunal. The first case was against the head of the security prison S-21, Kaing Guek Eav, known as Duch, and it is him and his trial which stand at the center of this book.

Man or Monster? is aimed at a readership interested in perpetrators of mass violence, transitional justice processes, and post-violence societies. In essence, the book looks at how transitional justice processes allow for various 'articulations' of the person being tried as a perpetrator and focuses on the story of Duch. The book serves well not only as a detailed study of these issues, but also as an introductory piece on the genocide of the Khmer Rouge and particularly the role of S-21, providing a complementary view to David Chandler's seminal work on this place from a very different perspective. ${ }^{1}$

Hinton describes his book as an 'ethnodrama' and it is structured along various roles ascribed to Duch, and then by various parties to the trials. The book draws on various literary genres in compiling a work which is artistic and scholarly, readable yet theoretically grounded, empirically rigorous and engaging yet approachable by people unfamiliar with the case. As the book draws on various literary forms, Man or Monster? includes an abecedarian on Duch, the Khmer Rouge and the trial with each line beginning with $\mathrm{A}, \mathrm{B}, \mathrm{C}$ and the next letters of the alphabet; an erasure drawing on the apology Duch made before the court which has redacted parts of the text to lay stronger emphasis on Duch's masking of the violence at S-21; and a cento, a poem that draws on various contrasting sources.

Furthermore, throughout the book Hinton includes various styles and approaches to provide a broad and encompassing perspective on the topics being studied. Striking are the first-person narratives and field journal entries telling of Hinton's own experiences at the trial and how he engaged with various actors of the judicial processes. Most prominently, this includes some of the prominent survivors and Hinton's experiences while visiting Tuol Sleng Genocide Museum on many occasions, which S-21 was turned into after the fall of the Khmer Rouge. Tuol Sleng, S-21 and the ECCC, are the two/three locations where most of the book plays out, adeptly reaching out to tell stories beyond this. The prominent positions of these places allow the reader to be walked through Tuol Sleng as a museum today, as well as feel what it means to those survivors who were once imprisoned here, and how they see it now as they peddle their wares and sell their stories on the grounds.

These accounts are intermingled with trial materials, sometimes verbatim, more often paraphrased, managing to engage the reader in a way which goes beyond scholarly practice and transport him or her as a silent witness peering over the shoulder of various actors at the tribunal. The reader is presented with key points during the trial, including key witnesses, Duch's apology, the verdict and appeals, and how the various participants at the court attempt to shape these events and use them to portray Duch in a certain light.

${ }^{1}$ David Chandler, Voices from S-21: Terror and History in Pol Pot's Secret Prison (Berkeley: University of California Press, 1999).

Timothy Williams, "Book Review: Man or Monster? The Trial of a Khmer Rouge Torturer" Genocide Studies and Prevention 10, 3 (2016): 98-100. $\odot 2016$ Genocide Studies and Prevention. 
S-21 takes a prominent position too, with Hinton providing the reader with details about the place as it was created, how it was run by Duch, the methods of torturous interrogation which were used, and how the prison managed to utterly dehumanize anyone who came through its gates. Accounts of Duch's life before S-21 are tied into these narratives in an attempt to show continuities through his life, to include his schooling and his passion as a math teacher, as well as his running of the M-13 prison camp during the civil war which preceded Democratic Kampuchea, as the country was called under the Khmer Rouge's reign. Broader historical explanations of how the Khmer Rouge regime ruled the country with an iron fist, implemented its genocidal ideology, and purged thousands of its own cadres are given, but always relating into the S-21 locality, telling the history of this period in Cambodia from the perspective of this infamous place.

Most prominently though, the book goes beyond a re-telling of Duch's, S-21's, or even Democratic Kampuchea's history, as it offers reflections on the meanings these places are imbued with today and how the perception of them differs culturally. Hinton takes this further to consider also the meaning various objects have for different people, such as a photograph of Chan Kim Srun, a woman photographed on her admittance to S-21 with her baby on her arm, or even the chair which these photos were taken on. Another example is a photograph of Duch displayed at Tuol Sleng, which has had various graffiti smeared on it, and Hinton has placed on the cover of his book, and how different cultural frames of mind will understand these graffiti in strongly diverging ways.

In the grand melange of influences in the book, finally, Hinton also puts forward various theoretical ideas and impulses as these relate to the many and diverse empirical topics already discussed. It is at once the book's main strength and weakness that he playfully integrates these various questions, ideas, and approaches throughout his material, as it leaves the book without a theoretical foundation as a whole, but provides beacons of insight throughout. From a theoretical or conceptual point of view, Hinton regularly throws in elucidating ideas which guide and support the wealth of empirical material he presents, but none provide an overarching framework.

The main ideas which run through the book are first, that of the 'redactic' or erasure. Hinton prompts his readers to think about the 'articulations' which are put forth by various actors and events (including us as readers in our own lives), and how these are redacted, what is left out and how different elements are backgrounded. He applies this to the "thick frames" of Khmer Rouge ideology, as well as to articulations of Duch at trial and of his survivors today. I would argue that any study necessarily reduces the complexity of reality, and Hinton is right in saying that "we must be wary of the maskings and obfuscations that are always present and that underlie the banality of everyday thought." 2 This is a useful, albeit slightly banal lens through which to view Duch's trial. But the book would not be significantly weakened without the redactic as a frame, and equally it is an idea which could be applied to any study of human beings in social situations. Hinton's point is well made, but it is slightly overlaboured.

Second, the 'essence' of who Duch actually is, is grappled with in the title of the book Man or Monster?, as well as in the title picture (the photograph of Duch with graffiti) are discussed in great depth throughout the book from various perspectives. Different perspectives can be found in portrayals in the media, by the prosecution, and through survivor testimony of Duch as a monster. He saw himself as a cog in the larger machine with little agency, just a man in a difficult situation; the judges deemed him to be a zealot who "exercised his authority actively, innovating, managing S-21, recruiting and training staff, participating in arrests, and reporting about and annotating confessions." ${ }^{3}$ Given how any articulation of who Duch is, is necessarily redacted, Hinton emphasizes the grey zones which appear to have been erased in such dichotomous approaches to seeing Duch as either man or monster, innocent or guilty. Various articulations emphasize different elements, thus automatically redacting others: meticulous zeal in fulfilling his obligation to the party; boastfulness about his torturous interrogation skill; an enthusiastic leader and teacher; prepared to invest everything for his party; a lack of empathy; differences in interpretation about

\footnotetext{
${ }^{2}$ Alex Hinton, Man or Monster? The Trial of a Khmer Rouge Torturer (Durham: Duke University Press, 2016), 266.

${ }^{3}$ Ibid., 237.
} 
how much sway he held in decisions regarding purges; and who was to be arrested or about how much he was actively involved in violence. While Duch remains at the center of these discussions, other actors are also studied, along with their characters, their motivations for their testimony, and their perspectives on the past and present.

A third recurring topic is that of hybridity or a disjuncture between the local (Cambodians) and the global (internationals), particularly in their diverging cultural understandings of the different processes, as well as different interests they have in them. The political Spiel surrounding the ECCC and its cases are central here, but also at a more fundamental level regarding conceptions of justice, responsibility, and forgiveness, particularly given the Western liberal view of the world on the one side and the Cambodian Buddhist perspective on the other. Some of the most interesting points and arguments new to the literature are in these discussions and it would have served the book well for these to have been foregrounded a little more.

As such, this book ties into other recent moves within the study of perpetrators of mass violence which tries to dissolve binary, black-and-white perspectives and highlight the grey zones and complexity of many actors involved in conflict. ${ }^{4}$ These works challenge us to contemplate the possibility that people such as Duch are not monsters, but are in a grey zone in which we ourselves are also located.

This book will become standard reading for anyone studying the portrayal of perpetrators during post-conflict justice processes or more specifically the trials at the ECCC, as well as those interested in the inner workings of S-21 and most certainly the personality of its leader Duch. In the end, Hinton does not want to provide definitive answers to concrete questions but wants to demonstrate ellipses, point towards paradoxes, culturally qualify and contextualise, provoke thought, challenge preconceptions, and raise questions. He achieves this objective fully and the reader finishes the book with the feeling of being empirically saturated with a wealth of fascinating details about the trials and its actors, Duch as a man and a monster, S-21 then, and Tuol Sleng Genocide Museum today. And yet, there remains a question mark of what the core message of this work is, which is unsettling for an academic book. However, it is a question mark the author certainly wants hanging over the book and one which challenges us to think deeper and further challenge our perspectives on this and other cases. To end with a short excerpt from the book, Man or Monster? is a plea for "'thoughtfulness,' a willingness to think critically and remain open to difference and the real-world complexities that we are inclined, by our existential anxieties and the banality of everyday thought, to pare down, edit and redact." ${ }^{5}$

\footnotetext{
${ }^{4}$ See Erin Baines, "Complex political perpetrators: Reflections on Dominic Ongwen," The Journal of Modern African Studies 47, no. 2 (2009): 163-191; Erin Jessee, Negotiating Genocide in Rwanda: The Politics of History (New York: Palgrave Macmillan, forthcoming); Timothy Williams, "'I am not, what I am.' A typological approach to individual (in)action in the Holocaust," in Probing the Limits of Categorization: The Bystander in Holocaust History, ed. Christina Morina and Krijn Thijs, (New York: Berghahn, forthcoming).

${ }^{5}$ Hinton, Man or Monster?, 295.
} 